\title{
Guest editorial: Professionalism, de-professionalisation and austerity
}

\author{
Stephen Crossley
}

It is generally acknowledged now that the programme of austerity undertaken by successive governments in the UK includes the restructuring of the state and not just the retrenchment of some of its traditional welfare functions. Changes in structural and governance arrangements have resulted in welfare professionals and those involved in the delivery of public services being located in a range of organisations spanning the public, private and voluntary sectors. Such changes at the macro-level inevitably lead to changes at the meso and micro level.

It is in this context that changes to the ways teachers and social workers, for example, are educated needs to be understood. There have been sustained efforts to fast-track the training of such professions, to reduce the amount of 'theory' that students are exposed to, and to remove training courses from universities, which (at times) are still spaces of critical and independent thought and scholarship. At a practice level, new 'professions' have been, and are continuing to be, smuggled into public services (many of these before the period of austerity commenced in 2010). In 'enforcement' and 'management' terms, we have seen neighbourhood or community 'wardens' and Police Community Support Officers (PCSOs) introduced in recent years. Education has seen Classroom and Teaching Assistants introduced to support teachers and pre-school professions such as Early Years Teacher and Early Years Teaching Assistant have also emerged. Social Work Assistants and Family Workers are now as likely to work with disadvantaged families as registered social workers are. In parallel developments, algorithms are increasingly used to decide on the allocation of resources (McQuillan, 2015) and there have even been proposals to replace probation officers with electronic kiosks in some cases (Doward, 2012).

These new professions and/or technological developments are usually cheaper than the recruitment, training and employment of the more established public-sector professions. In some cases, the 'new' professions' have been positioned directly against their more expensive counterparts, as has happened with family workers and social workers. The Troubled Families Programme (TFP), one of the most high-profile social policies of the coalition government, and at the forefront of attempts to re-craft the state (Crossley, 2016), advocates a 'family intervention' approach that is proposed as both a return to 'good old fashioned social work' and a solution to the professions contemporary failings. The 'family intervention' approach purportedly requires a single keyworker working intensively with 'problem' or 'troubled' families, whilst 'gripping' 
other services involved with the family or its individual members. The hands-on 'persistent, assertive and challenging' approach of family workers has been contrasted with the putative approach of contemporary social workers and other officials who, in the words of Louise Casey, the former senior civil servant previously in charge of government efforts to tackle 'troubled families', 'circle' (House of Commons Committee of Public Accounts, 2014: 21) and 'assess the hell' out of families' (Ibid: 42) but 'don't actually make any difference' (in Bennett, 2012: 15). Family workers are expected to 'don the marigolds', 'roll their sleeves up', 'scrub floors' and 'get stuck in' in myriad ways according to Casey and official government documents (see Bennett, 2012; DCLG, 2012, Winnett and Kirkup, 2012) went further in an interview with the Telegraph, telling them that the TFP was not 'some cuddly social workers' programme to wrap everybody in cotton wool' (in Winnett and Kirkup, 2012).

The first phase of the Troubled Families Programme was, according to the government, 99\% successful in 'turning around' the lives of 'troubled families'. If such a programme and the approach it adopts can work so successfully with some of the most disadvantaged families, at a time of austerity and punitive welfare reforms, what need is there for social workers?

The argument that the family work approach is akin to 'old fashioned social work' (Gentleman, 2013) helps to portray not just a rose-tinted view of the history of social work interventions, but also locates today's social workers and contemporary social work practice as part of the problem, and thus ripe for 'reform'. The symbolic privileging of 'family work' over 'social work' - and the clear distinction between the two - helps to concentrate the policy gaze on 'the family' in the same way that the focus on workers who can 'get through the front door' helps to close off discussions about structural disadvantages and social injustice, issues that both traditionally and contemporaneously concern social workers. The symbolic and political capital delegated to and invested in family workers should, like the idea of Emma Harrison's 'family champions' before them, be understood, in terms of social work practice, as one of number of 'developments on the margins of mainstream practice ... likely to be significant' (Garrett, 2015: 14). The privileging of 'attitude' over 'knowledge' or 'experience' should also be of concern to social workers who have often struggled to create or maintain their professional status.

This edition of Social Work \& Social Sciences Review is, then, very timely and much needed. To date, there has been a lot written about the effects of austerity measures and welfare reforms on the ultimate recipients and users of welfare services. Much less attention has been focused on what such reforms mean for those tasked with implementing (or negotiating, subverting or resisting) them. Social workers have a long history of working 'in and against the state' (London to Edinburgh Weekend Return Group) and the extensive literature on the applicability of theories of 'street-level bureaucracy' (Lipsky, 1980) to social work highlights the ways that social workers have often used the discretion afforded them to soften the impact of some of the states more 
punitive policies. But if, as Stuart Hall (2011) argued, the neoliberal project and the programme of austerity unleashed by the coalition government represents 'the most radical far-reaching and irreversible social revolution since the war', the effects of that revolution on frontline agents of the state requires attention.

The four articles in this special issue provide a good framework for interrogating the impact of austerity on professions and the process of de-professionalisation. Nigel Malin presents a brief introduction to theoretical frameworks used for studying professions. He examines Durkheimian, Weberian, Marxist and post-structuralist theories, amongst others, and sets the scene for the other papers in the issue, highlighting the relevance of theoretical approaches and structural arrangements to professionals. Michael Lavalette summarises some of the effects of austerity measures across different social policy areas, highlighting the terrain in which many social workers and other public-sector workers operate. He examines labour market changes which force people into precarious and low-paid employment, before also discussing increasing housing insecurity and the shorter-term, increasingly individualised policy 'solutions' to health and social care issues.

Jane Tunstill and Carolyne Willow provide a fascinating 'insider' account of the campaign against the 'exemption clauses' in the Children and Social Work Act 2017. They examine the professional identity and integrity of social work professionals who are increasingly asked to facilitate, rather than fight, the UK Government's austerity policies. They highlight the callous absurdity of the government's 'red tape challenge' when applied to safeguards and checks on the rights of vulnerable children and use the case study of the campaign to ask important questions about social workers future role, at a time when their existing one is under threat.

Malin then provides a comprehensive and extensive explication of the processes of de-professionalisation under the austerity agenda, examining a range of social policy areas and drawing on different case studies. The different sections of his article cover: theoretical definitions of de-professionalisation; a review of de-professionalisation through the lens of austerity; a case study of the junior doctors' strike; and reviews of the evidence in relation to training cuts, a decrease in staff morale, and a reduction in productivity.

The special issue serves as a timely reminder that the programme of austerity undertaken by UK governments in recent years does not just affect the end users of public services in the short-term. Austerity measures and neoliberal welfare reforms are intended to re-shape and re-structure the state, the way it provides services, who provides them, and the demands it places upon individuals over the longue durée.

Stephen Crossley

Senior Lecturer in Social Policy

Department: Social Work, Education \& Community Wellbeing

Northumbria University

stephen.crossley@northumbria.ac.uk 


\section{References}

Bennett, R. (2012) Local authority officials 'should scrub floors', The Times, April 27th

Crossley, S. (2016) 'Realising the (troubled family)', 'crafting the neoliberal state'. Families, Relationship and Societies, 5, 2, 263-279.

DCLG (2012) Working with Troubled Families. London: DCLG.

Doward, J. (2012) Probation officers to be replaced by electronic kiosks in pilot scheme. The Guardian, April 28th

Garrett, P. M. (2013). Children and Families. Bristol: Policy Press.

Gentleman, A. (2013) Troubled families: 'You need to do something bad before you get support'. The Guardian, April 7th

Hall, S. (2011) The march of the neoliberals. The Guardian, September 12th

House of Commons Committee of Public Accounts (2014) Uncorrected Transcript of Oral Evidence: Programme to help families facing multiple challenges, Public Accounts Committee, 29 January. http://www.parliament.uk/documents/commons-committees/public-accounts/ PAC-290114.pdf

Lipsky, M. (1980) Street-level Bureaucracy; Dilemmas of the individual in public services. New York: Russell Sage Foundation.

London Edinburgh Weekend Return Group (1980) In and Against the State, London: Pluto Press. McQuillan, D. (2015) Algorithmic states of exception., European Journal of Cultural Studies, $18,4-5,564-576$

Winnett, R. and Kirkup, J. (2012) Problem families have 'too many children', The Telegraph, July 20th http://www.telegraph.co.uk/news/politics/9416535/Problem-families-have-toomany-children.html 